http://dx.doi.org/10.12775/szhf.2016.063

PaWEe HanczewsKi

Uniwersytet MikoŁaja Kopernika, Toruń, Polska

PH@UMK.PL

\title{
David Hume: czy ekonomia może być nauką?
}

Spośród esejów, których David Hume nie napisał, w najbardziej dotkliwy sposób odczuwam brak tekstów zatytułowanych $O$ religii oraz Czy ekonomia może być nauką?. Można argumentować, że Hume przedstawił swoje opinie na każdy z tych tematów w sposób fragmentaryczny w innych pracach, które łącznie dają pełny obraz jego poglądów. Jednak sprawa nie jest oczywista.

Kwestią sporną jest już to, co Hume rozumiał pod pojęciem „nauka”. W Badaniach dotyczacych rozumu ludzkiego wyróżnił nauki abstrakcyjne, których przedmiotem są „,wielkość i liczba”, nauki zajmujące się „faktami szczegółowymi", do których zaliczył historię, chronologię, geografię i astronomię, nauki zajmujące się „faktami ogólnymi”, czyli takie, „gdzie badane są jakości, przyczyny i skutki całych rodzajów przedmiotów", wymieniając wśród nich politykę, filozofię przyrody, medycynę, chemię oraz, niestety nieokreśloną, kategorię „etc”. Ostatni rodzaju nauki to teologia ${ }^{1}$. Czy i do której z tych kategorii można zaliczyć ekonomię?

Hume nie ułatwił odpowiedzi, mnożąc wątpliwości w kwestiach, które, wydaje się, przedstawił w jednoznaczny sposób. Przykładem są rozważania

${ }^{1}$ D. Hume, Badania dotyczące rozumu ludzkiego wraz z apendyksami, przeł. D. Misztal i T. Sieczkowski, Kraków 2004, s. 130-133. 
dotyczące polityki. W jednym z najbardziej znanych esejów: Czy polityka może być nauką? argumentował, że polityka była nauką na równi z chemią czy medycyną, ponieważ w jej skład wchodziły „prawdy ogólne” czy też zasady o „uniwersalnym charakterze”, niezależne od działań ludzkich². Uniwersalny charakter zasad polegał na tym, że działały zawsze w taki sam sposób, przynosząc identyczne efekty, w każdym miejscu i czasie. Jak zauważył, rezultaty użycia zasad „możemy przewidzieć z dokładnością i pewnością równą niemal naukom matematycznym" ${ }^{3}$, z czego wniosek, że to zasady w postaci norm prawnych i form rządu kształtowały i kształtują postępowanie jednostek oraz społeczeństw, nie odwrotnie. Stąd porównania między starożytną Grecją, Kartaginą, Rzymem i Persją a współczesną Francją, Anglią, Irlandią czy Wenecją, przy czym państwa pierwszej grupy dostarczały przykładu, jaka forma rządu jest najlepsza dla państw istniejących w drugiej połowie XVIII wieku.

Jednak w eseju $O$ wolności obywatelskiej podał w wątpliwość uniwersalny charakter polityki jako nauki, wskazując, że ludzka wiedza i doświadczenie są zbyt ograniczone, aby formułować „wiele ogólnych twierdzeń politycznych, które zachowywałyby prawdziwość aż do najodleglejszych pokolen'”4. Innym elementem przyczyniającym się do stanu niepewności były gwałtowne zmiany, które przekreślały wszystkie przewidywania. Wniosek był taki, że „wszelkie twierdzenia, jakie byśmy wysunęli w tej kwestii [relacje między wolnością obywatelską a rządem absolutnym], podważy najprawdopodobniej przyszłe doświadczenie, a tym samym zostaną one odrzucone przez przyszłe poko-

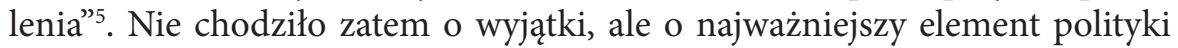
jako nauki, czyli jej uniwersalny charakter.

Dorobek Hume’a w dziedzinie ekonomii składa się z kilku esejów, które, z wyjątkiem eseju $O$ zawiści w handlu, opublikowanego w 1758 roku, ukazały się w 1752 roku. W części otwierającej pierwszy tekst ekonomiczny O handlu przywołał wcześniejsze spostrzeżenia dotyczące najważniejszego zadania filozofów i polityków, czyli poszukiwania zasad ogólnych, które, mimo wyjątków, „muszą zawsze wziąć górę w ogólnym biegu rzeczy”. Odwołanie, nawiązując do koncepcji polityki jako nauki, wskazuje, że Hume w podobny

${ }^{2}$ D. Hume, Czy polityka może być nauka??, [w:] tenże, Eseje z dziedziny moralności, polityki i literatury, przeł. Ł. Pawłowski, Warszawa 2013, s. 22, 24, 31.

3 Tamże, s. 22, 26.

${ }^{4}$ D. Hume, O wolności obywatelskiej, [w:] tenże, Eseje..., s. 72.

5 Tamże, s. 73.

${ }^{6}$ D. Hume, O handlu, przeł. S. Zabieglik, „Nowa Krytyka” 2007, t. 20-21, s. 441. 
sposób spoglądał na ekonomię, a więc jako na naukę, w której możliwe jest określenie uniwersalnych zasad. I tutaj pojawiają się wątpliwości. Prac Hume’a dotyczących ekonomii nie można oddzielić od jego pozostałych tekstów, które nie są bezpośrednio związane z problematyką gospodarczą. Hume kierował się regułą, którą sformułował w Traktacie o naturze ludzkiej: „Jest rzeczą oczywistą, że wszystkie nauki pozostają w pewnym stosunku... do natury ludzkiej; i że choćby która $\mathrm{z}$ nich nie wiedzieć jak wydawała się oddalona od tej natury, to przecież wszystkie one powracają do niej na tej czy innej drodze" . Kierował się też powszechnym w XVIII wieku poglądem, że natura ludzka, pokonując bariery miejsca i czasu pozostaje taka sama: „powszechnie uznaje się fakt, iż zachowanie ludzi wszelkich nacji i epok cechuje wielka jednolitość i że natura ludzka wciąż pozostaje niezmienna co do swych zasad i działań". Jednak w tym samy dziele Hume zwrócił uwagę, że niezmienna natura ludzka jest tylko określeniem ogólnym, istnieje przecież wielość charakterów i opinii, co powoduje, że w tej samej sytuacji ludzie postępują bardzo różnorodnie ${ }^{9}$. W rezultacie dopuszczał nieprzewidywalność ludzkich zachowań oraz istnienie licznych wyjątków ${ }^{10}$.

Jedną z cech charakterystycznych prac ekonomicznych Hume'a jest zatem połączenie uwag dotyczących skomplikowanej natury ludzkiej z rozważaniami na temat gospodarki, a to nie ułatwia znalezienia „zasad ogólnych”. Zadania nie upraszcza też fakt, że Hume, formułując zasady, łączył je z radami, jakie działania należy podjąć, aby zapewnić rozwój gospodarczy państwa. Innymi słowy, rozważaniom na temat ekonomii jako nauki złożonej z zasad ogólnych towarzyszyły rozważania na temat polityki ekonomicznej.

Za punkt wyjścia dla poszukiwania „zasad ogólnych” Hume’a na temat ekonomii można przyjąć zdanie ze wspomnianego eseju $O$ handlu: „Praca pozwala nabyć każdą rzecz na tym świecie, a do pracy motywują nas jedynie nasze namiętności”"11. Jest ono świetną ilustracją wspomnianego związku między ekonomią a naturą ludzką. W pierwszej części wskazuje na to, czym jest bogactwo i skąd pochodzi, w drugiej wskazuje na źródła aktywności

${ }^{7}$ D. Hume, Wstęp, [w:] tenże, Traktat o naturze ludzkiej, przeł. C. Znamierowski, Warszawa 2005, s. 78.

${ }^{8}$ Tenże, Badania dotyczące rozumu..., s. 69.

9 Tamże, s. 71.

${ }^{10}$ Szerzej na temat poglądów Hume’a dotyczących związków między naturą ludzką a ekonomią, patrz: K. Kopczyńska, S. Zabieglik, Psychologia ekonomiczna Davida Hume’a, „Nowa Krytyka” 2007, t. 20-21.

${ }^{11}$ D. Hume, O handlu..., s. 448. 
gospodarczej tkwiące w naturze człowieka. Ostatni punkt Hume rozwinął w innej ze swoich prac, nadając mu charakter uniwersalny: „Chciwość czy też żądza zysku to namiętność powszechna, która oddziałuje na wszystkich, niezależnie od miejsca i czasu”" ${ }^{2}$. Czy w takiej sytuacji „zasady ogólne” ekonomii miały taki sam charakter jak w przypadku polityki, a więc były niezależne od ludzi, czy też natura ludzka miała na nie wpływ? A może zachodziła jeszcze inna zależność, polegająca na tym, że to „zasady ogólne” ekonomii kształtowały postawy ludzi? Pytania są uzasadnione, ponieważ opisując mechanizmy rządzące ekonomią, Hume często odwoływał się do swoich poglądów na temat natury ludzkiej. Sięgał również po metodę historyczną, zgodnie z zasadą wyrażoną w eseju $O$ studiowaniu historii: ,historia jest nie tylko wartościową dziedziną wiedzy, lecz także wiedzie ona do wielu innych dziedzin oraz dostarcza przedmiotu badań dla większości nauk" ${ }^{13}$. Pisząc o roli pieniądza, odwoływał się do przykładów ze starożytności, począwszy od Kartaginy ${ }^{14}$; podobnie było $\mathrm{w}$ przypadku handlu zagranicznego ${ }^{15}$. Równocześnie Hume dostrzegał istotne różnice między gospodarkami w czasach starożytnych i w połowie XVIII wieku. Pieniądz czy handel międzynarodowy funkcjonowały w obydwu epokach, ale w odmiennych warunkach. W starożytności istniało niewolnictwo, częściej dochodziło do konfliktów zbrojnych, wyraźnie niższy był też poziom rozwoju gospodarczego. Hume wyróżnił w historii kilka faz rozwoju ekonomicznego, począwszy od łowiectwa i zbieractwa, przez rolnictwo po współczesną mu gospodarkę opartą na produkcji i handlu, wyraźnie je sobie przeciwstawiając i pisząc z jednej strony o „wcześniejszych prostszych i nieokrzesanych czasach”, a z drugiej o czasach „gdy rozwija się przemysł i uszlachetniają się [rozrywki]”. Dopiero w tej ostatniej fazie możliwe było wyjście poza zaspokajanie podstawowych potrzeb ludności i rozwój handlu, a co za tym idzie, wyraźny wzrost bogactwa ${ }^{16}$. Wielki wpływ na gospodarkę miały więc czynniki zewnętrzne, takie jak formy organizacyjne czy struktura społeczna, a to znajdowało odzwierciedlenie nie tylko w dominacji rolnictwa bądź rzemiosła i handlu, ale także w skali użycia pieniądza. Jeśli Hume traktował ekonomię jako naukę z „zasadami ogólnymi”, to zasady te odnosił raczej do czasów sobie współczesnych niż do wszystkich czasów.

\footnotetext{
12 Tenże, O narodzinach i postępie sztuk i nauk, [w:] tenże, Eseje..., s. 84.

${ }^{13}$ Tenże, O studiowaniu historii, przeł. P. Michalski, „Nowa Krytyka” 2007, t. 20-21, s. 491.

${ }_{14}$ Tenże, O pieniądzu, przeł. A. Grzeliński, „Studia z Historii Filozofii” 1(5)/2014, s. 10.

15 Tenże, O równowadze handlu, przeł. D. Kosiewicz-Wawrzonkowska, „Studia z Historii Filozofii” 1(6)/2015, s. 38-40.

${ }_{16}$ Tenże, O pieniądzu..., s. 17-18.
} 
Słowa „Praca pozwala nabyć każdą rzecz na tym świecie” prowadzą do bardzo ważnego zagadnienia dotyczącego bogactwa i jego pochodzenia. Hume połączył rozważania nad tą kwestią z innym szeroko dyskutowanym problemem, jakim była rola pieniądza w gospodarce. Nie utożsamiał bogactwa z pieniądzem kruszcowym czy papierowym. O roli pieniądza pisał szczegółowo w esejach $O$ pieniądzu i $O$ procencie, ale w gruncie rzeczy dotykał tego problemu we wszystkich swoich pracach ekonomicznych. Jego celem było zakwestionowanie tego, co uważał za obiegowe opinie na temat pieniądza. Nie przypisywał pieniądzowi kluczowego znaczenia w życiu gospodarczym. W pierwszej kolejności uznał, że pieniądz, nazwany przezeń „oliwą, która sprawia, że ruch owych kół [handlu] jest bardziej płynny i łatwy", był niczym więcej niż środkiem ułatwiającym obrót gospodarczy, przede wszystkim handel, oraz środkiem odzwierciedlającym wartość pracy i towarów ${ }^{17}$. Sformułował przy tym opinię, że ceny są uzależnione do ilości pieniądza w obiegu oraz ilości dostępnych towarów ${ }^{18}$. Wyjątek od tej reguły stanowiła sytuacja, kiedy napływ pieniądza do jednego państwa był tak duży, że prowadził w nim do wzrostu cen i kosztów pracy, podczas gdy inne państwa, nie doświadczając wzrostu napływu pieniądza, zachowywały niższe ceny, co zwiększało ich możliwości konkurencyjne. Wówczas pierwsze państwo znajdowało się w niekorzystnym położeniu w wymianie międzynarodowej. Jednak pomijając taką sytuację, którą uważał za nadzwyczajną i wynikającą z przyczyn niezwiązanych z aktywnością gospodarczą, na przykład odkryciem nowych złóż szlachetnych kruszcó $w^{19}$, twierdził, że ilość pieniądza w każdym państwie zmierza do stanu równowagi z ilością pracy i towarów ${ }^{20}$. Jeśli taki mechanizm nie działał, to albo we wspomnianej sytuacji napływu zbyt wielkiej ilości pieniądza, albo dlatego, że duża część pieniędzy znajdowała się w rękach nielicznej grupy, utrudniając czy nawet uniemożliwiając ich obrót. W ostatnim przypadku wina znajdowała się jednak nie po stronie „uniwersalnych zasad” ekonomii, lecz tego, że ludzie „żyją w prosty, dawny sposób", który nie stwarzał zachęty do zaspokajania innych potrzeb niż podstawowe, a tym samym do rozwoju ekonomicznego ${ }^{21}$. Stąd między innymi pochwały Hume’a dla wystawnego stylu życia i luksusowej konsumpcji, które, dzięki tworzeniu popytu i przyspieszeniu obiegu pieniądza, przyczyniały się

\footnotetext{
17 Tamże, s. 9, 12.

18 Tamże, s. 16.

19 Tamże, s. 12-13.

${ }^{20}$ Tamże, s. 11-12.

${ }^{21}$ Tamże, s. 19-20.
} 
do rozwoju ekonomicznego ${ }^{22}$. Gospodarka potrzebowała stałego, choć powolnego wzrostu ilości pieniądza, ponieważ sprzyjało to aktywności gospodarczej, natomiast zmniejszenie ilości pieniądza było niepożądane, ponieważ mogło prowadzić do spadku aktywności ${ }^{23}$. Hume zwrócił przy tym uwagę, że wprowadzenie nowych pieniędzy nie przynosi natychmiastowego oraz jednakowego efektu dla wszystkich uczestników życia gospodarczego. Korzyści $\mathrm{z}$ nowego pieniądza uzależnione są od tego, w którym momencie pieniądz do nich dotrze. W ten sposób wprowadził do swoich rozważań na temat pieniądza element, który znacznie później zyska nazwę „zmienna czasowa” i stanie się ważną częścią nauk ekonomicznych ${ }^{24}$. Z ilością pieniądza w gospodarce łączył także kwestię stóp procentowych i długu publicznego. W pierwszym przypadku odrzucił pogląd, że wysokość stóp procentowych jest uzależniona od ilości pieniądza w obiegu, zgodnie z zasadą, że im więcej pieniądza, tym niższe koszty pożyczek. Wysokość stóp procentowych była zależna od stopnia rozwoju gospodarczego, szczególnie wytwórczości rzemieślniczej i handlu. Im bardziej rozwinięte państwa, tym więcej osób i instytucji, które są gotowe pożyczać pieniądze, a w rezultacie niższe koszty kredytu ${ }^{25}$. Jeśli chodzi o dług publiczny, to, korzystając z przykładów historycznych, wskazywał na związane z nim korzyści, takie jak rozwój rynku kapitałowego i związane z tym niższe koszty pożyczek. Równocześnie jednak, odwołując się do sytuacji współczesnej Wielkiej Brytanii, widział go jako zagrożenie ze względu na zbyt wielkie zadłużenie ${ }^{26}$.

Skoro pieniądz nie był tożsamy z bogactwem, to czym było bogactwo i skąd pochodziło? Bogactwo, jak napisał, to: „publiczny spichlerz zbożowy, magazyn tkanin, arsenał broni”, dodając bezpośrednio po tym: „handel i przedsiębiorczość są w rzeczywistości niczym innym, jak zasobem siły roboczej”27. Źródłem bogactwa była zatem ludzka praca, dzięki której wytwarzano towary rolne i przemysłowe - bogactwa, które po zaspokojeniu podstawowych potrzeb mogły być przedmiotem handlu. Hume szczególnie dużo miejsca poświęcił handlowi zagranicznemu, widząc w nim nie „oliwę" gospodarki, ale

${ }^{22}$ D. Hume, O doskonaleniu sztuk, [w:] tenże, Eseje..., s. 186-198.

${ }^{23}$ Tenże, O pieniądzu..., s. 15.

${ }^{24}$ Tamże, s. 13-15.

${ }_{25}$ Tenże, O procencie, przeł. A. Grzeliński i K. Wawrzonkowski, „Studia z Historii Filozofii” 4(5)/2014, s. 43.

${ }^{26}$ Tenże, O kredycie publicznym, przeł. A. Grzeliński i A. Markwart, „Studia z Historii Filozofii” 1(7)/2016, s. 56-70.

27 Tenże, O handlu..., s. 449. 
jedno z jej kół zamachowych. Negował pogląd, że handel zagraniczny może przyczyniać się do zubożenia państw poprzez odpływ pieniędzy. Handel zagraniczny prowadził do wzrostu bogactwa. Nie stanowił gry o sumie zerowej, której celem było wzbogacenie się cudzym kosztem. Handel międzynarodowy zapewniał korzyści wszystkim stronom i był formą współpracy, nie rywalizacji między państwami, które tworzyły system naczyń połączonych, a ich dobrobyt był zależny od siebie nawzajem ${ }^{28}$. Sprzyjała temu sama natura, „rodząc w różnych krajach rozmaitość geniuszy, klimatów i ziem”" ${ }^{29}$, zapewniała, że żadne państwo nie będzie w pełni samowystarczalne, skłaniając je tym samym do współpracy. Handel międzynarodowy był formą współpracy również z tego powodu, że wykazywał tendencję do stanu równowagi, czyli takiej, w której wartość eksportu i importu każdego z państw jest zbliżona. Wzrost bogactwa jednego tylko państwa poprzez wysoką nadwyżkę w handlu, której jednym $z$ efektów był zwiększony napływ pieniądza, stwarzał bardzo niebezpieczną sytuację. W krótkiej perspektywie jego następstwem był wzrost cen i spadek konkurencyjności na rynkach międzynarodowych, natomiast $\mathrm{w}$ dłuższej prowadził do ruiny wszystkich uczestników handlu międzynarodowego, łącznie z państwem, które w pewnym momencie osiągnęło przewagę. Celem wymiany międzynarodowej nie było pozyskanie jak największej ilości pieniędzy kosztem innych państw i nie na tym polegały korzyści z niego. Handel międzynarodowy polegał na wymianie towarów, a w ostatecznym rachunku na wymianie pracy, przyczyniając się do rozwoju wszystkich jego uczestników dzięki zwiększeniu produkcji ograniczonej już nie tylko do potrzeb rynku krajowego, ale skierowanej także na rynek zewnętrzny. Zwiększenie produkcji wymagało zwiększenia zatrudnienia, dzięki czemu więcej ludzi, wykonując więcej pracy, mogło żyć w lepszych warunkach, podnosząc ogólny poziom bogactwa ${ }^{30}$. Handel zagraniczny dawał impuls do rozwoju całej gospodarki, nie tylko przez zwiększanie produkcji, ale także poprzez wpływ na postawy ludzi. Dzięki handlowi mieli możliwość poznania "przyjemności... z przepychu i smak zysku". W ten sposób handel „wytrąca ludzi z inercji”, zachęcając ich do pracy i dając im możliwość zaspokojenia chęci wzbogacenia się, a to wprowadza element rywalizacji, niezwykle istotny dla gospodarki jako całości ${ }^{31}$. Towary napływające $\mathrm{z}$ zagra-

\footnotetext{
${ }^{28}$ Tenże, O pieniq̨dzu..., s. 10-11; tenże, O zawiści w handlu, przeł. K. Wawrzonkowski, „Studia z Historii Filozofii” 4(6)/2015, s. 46-47.

${ }^{29}$ Tenże, O zawiści w handlu..., s. 47.

${ }^{30}$ Tenże, $O$ procencie..., s. 42.

${ }^{31}$ Tenże, $O$ handlu..., s. 450; tenże, $O$ procencie..., s. 42-43.
} 
nicy zmuszały krajowych producentów do bezustannego ulepszania swoich produktów ${ }^{32}$. Temu właśnie czynnikowi Hume przypisał wzrost gospodarczy Wielkiej Brytanii, zarówno w przeszłości, jak i obecny ${ }^{33}$. Handel zagraniczny, wprowadzając element konkurencji, dostarczał impulsu do stałego rozwoju ekonomicznego, a mechanizm ten, raz wprawiony w ruch, funkcjonował w nieprzerwany sposób: „Współzawodnictwo, które naturalnie rodzi się między tymi krajami jest oczywistym źródłem rozwoju" ${ }^{34}$. Konsekwencją takiego rozumowania był pogląd, że ilość bogactwa nie była ograniczona przez czynniki zewnętrzne, takie jak ilość szlachetnych kruszców. Ilość bogactwa, zależna od ilości wykonanej pracy, była ograniczona jedynie wielkością populacji i zdolnością rządzących do odpowiedniego wykorzystania potencjału ludnościowego. Stąd kolejna „zasada ogólna” mówiąca, że istnieje bezpośredni związek między bogactwem i siłą państwa oraz między bogactwem i siłą państwa a pomyślnością ogółu jego mieszkańców. O sile współczesnego państwa, w przeciwieństwie do czasów starożytnych, nie decydowała potęga militarna oraz kultywowanie cnót żołnierskich i obywatelskich, lecz bogactwo wytworzone przez jego mieszkańców. W ten sposób Hume połączył bogactwo i siłę państwa $\mathrm{z}$ naturalnymi dążeniami ludzi, których realizacja była niezbędna do osiągnięcia przez nich stanu szczęścia: „A zatem, zgodnie z najbardziej naturalnym biegiem rzeczy, przemysł, rzemiosła i handel zwiększają zarówno siłę monarchy, jak i poczucie szczęścia poddanych" ${ }^{35}$. Państwo nie mogło być bogate i silne kosztem ogółu swoich obywateli. Mechanizm był dokładnie odwrotny, bogactwo i siła państwa zależały od pomyślności jednostek ${ }^{36}$.

Z powyższych zasad wynikały poglądy Hume’a na temat polityki gospodarczej. Głównym celem działań państwa nie powinno być dążenie do uzyskania jak największej ilości pieniędzy, ponieważ to nie one decydowały o bogactwie i sile. Kluczowe znaczenie dla bogactwa i siły państwa miały produkcja oraz rozwój handlu i na ochronie tych dziedzin powinna koncentrować się polityka państwa, która mogła pójść w dwóch kierunkach. Państwo mogło sięgnąć po środki przymusu, zmuszając obywateli do pracy. Hume odrzucił to rozumowanie, podkreślając, że było ono charakterystyczne dla takich państw jak starożytna Sparta. Skopiowanie takiego rozwiązania było wówczas bardzo trudne, jeśli w ogóle możliwe, a to ze względu na odmienną sytuację:

\footnotetext{
${ }^{32}$ Tenże, O handlu ..., s. 450.

${ }^{33}$ Tenże, O zawiśsi w handlu..., s. 46-47.

${ }^{34}$ Tenże, O narodzinach i postępie..., s. 89; tenże, O zawiści w handlu..., s. 48.

35 Tenże, $O$ handlu..., s. 447.

${ }^{36}$ Tenże, O pieniądzu..., s. 19-20; tenże, O zawiści w handlu..., s. 47.
} 
„tamta polityka [starożytna] opierała się na gwałcie i stała w sprzeczności z naturalniejszym i zwyklejszym biegiem rzeczy”. Znacznie rozsądniejsze było „wychodzenie naprzeciw powszechnej skłonności rodzaju ludzkiego" ${ }^{37}$, a ta polegała na wspomnianym dążeniu jednostek do bogacenia się. Należało zatem pozostawić gospodarkę jednostkom, czerpiąc korzyści z ich działań poprzez odpowiedni system podatkowy, który powinien znaleźć równowagę między potrzebami finansowym państwa a dążeniem jednostek do wzbogacenia się ${ }^{38}$. Państwo poprzez swoją nieprzemyślaną politykę, przede wszystkim „dążenie do pieniądza”, mogło zniszczyć życie gospodarcze, najpierw rujnując handel i rzemiosło i ograniczając aktywność do rolnictwa, po to, aby ostatecznie zniszczyć i tę część ekonomii. Doprowadzenie do takiej sytuacji było łatwe, wystarczyło zniechęcić ludzi do pracy, pozbawiając ich płynących $\mathrm{z}$ niej korzyści materialnych ${ }^{39}$. Innym zadaniem państwa było stworzenie warunków, w których jednostki będą mogły między sobą konkurować. Hume akceptował istnienie różnic majątkowych, ale równocześnie uważał, że korzystne jest, aby bogactwo było jak najbardziej rozpowszechnione, ponieważ dążenie do równości w tym zakresie nie tylko odpowiada naturze ludzkiej, ale przyczynia się też do wzrostu bogactwa i siły państwa ${ }^{40}$. Państwo nie powinno zatem angażować się bezpośrednio w gospodarkę, lecz pełnić funkcję stróża, który zabiega o to, aby warunki uczestnictwa w życiu ekonomicznym były jednakowe. Takie stanowisko wydaje się sytuować Hume’a wśród zwolenników liberalizmu gospodarczego. Jednak jego poglądy na temat handlu zagranicznego każą postawić znak zapytania. Hume dostrzegał liczne korzyści płynące $z$ handlu międzynarodowego, przyjmując, że tak jak pozostałe dziedziny aktywności gospodarczej, należy zostawić go w rękach jednostek. Równocześnie jednak uważał podatki na towary konsumpcyjne, również importowane, za najlepszy rodzaj obciążeń podatkowych ${ }^{41}$. Opowiadał się też za cłami na towary zagraniczne w celu ochrony rodzimej produkcji, przede wszystkim tych jej rodzajów, które były słabiej rozwinięte niż u konkurencji zewnętrznej ${ }^{42}$.

\footnotetext{
37 Tenże, O handlu..., s. 445-447.

38 Tenże, O podatkach, przeł. S. Zabieglik, „Pieniądze i Więź” 2000, R. 2, nr 2 (7) wiosna, s. $41-42$.

${ }^{39}$ Tenże, O handlu..., s. 448.

${ }^{40}$ Tamże, s. 451.

${ }^{41}$ Tenże, $O$ podatkach..., s. 41.

${ }^{42}$ Tenże, O równowadze handlu..., s. 41.
} 
Przedstawione opinie Hume'a na temat ekonomii i polityki gospodarczej nie pozwalają udzielić jednoznacznej odpowiedzi na tytułowe pytanie „czy ekonomia może być nauką?”. Odpowiedź jest bowiem uzależniona od tego, o jakim wymiarze ekonomii mówimy. Na poziomie teorii ekonomia jest według Hume’a nauką. W esejach znajdziemy „zasady ogólne”, niezależne od człowieka, na przykład, że poziom cen dostosowuje się do ilości pieniądza w obiegu oraz ilości dostępnych towarów czy zasadę, że źródłem bogactwa jest praca, nie pieniądz. Co więcej, znajdziemy też „zasady ogólne”, które wpływają na postawy ludzi, na przykład zasadę, że niskie podatki wprowadzane w stopniowy sposób zachęcają ludzi do pracy, podczas gdy zbyt wysokie, arbitralnie wprowadzane obciążenia zniechęcają ich do aktywności gospodarczej ${ }^{43}$. Kiedy jednak przyjąć inny punkt widzenia i zastanowić się nad zastosowaniem teoretycznych założeń, sprawa przestaje być oczywista. Pomijając to, że „zasady ogólne” nie miały charakteru uniwersalnego w czasie i były uzależnione od etapu rozwoju ludzkości, to, jak zauważył Hume, człowiek jest tak zmienną istotą, ulegając tak wielu opiniom i zwyczajom, że „to, co może być prawdą, gdy trzyma się on jednego sposobu myślenia, okaże się fałszem, gdy opowie się za przeciwnymi obyczajami i poglądami”"44. W przypadku ekonomii najpoważniejszą konsekwencją było to, że ludzie mogli podważyć wszystkie jej zasady, a nawet doprowadzić do stłamszenia naturalnego dążenia do bogactwa leżącego u podstaw wszelkiej działalności gospodarczej. Działania człowieka nie były kształtowane przez bezimienne siły pozostające poza jego kontrolą, to człowiek mógł wpływać na ekonomię. Jednak nie w ten sposób, że zmieniał charakter „zasad uniwersalnych”, ale w ten, że mógł tworzyć warunki, w których zasady te nie funkcjonowały bądź ulegały wypaczeniom. Uzasadnione wydaje się zatem stwierdzenie, że przedstawiając ekonomię jako naukę zawierającą "prawdy ogólne” czy też zasady o „uniwersalnym charakterze”, Hume, mimo że przywoływał liczne przykłady z przeszłości i czasów sobie współczesnych, tworzył raczej model niż opisywał istniejącą sytuację. Jego prace ekonomiczne dostarczają znacznie więcej informacji o teorii ekonomii niż o życiu gospodarczym.

Wątpliwości dotyczą także miejsca Hume’a w historii myśli ekonomicznej. Jego eseje o ekonomii zostały opublikowane kilkanaście lat przed ukazaniem się fundamentalnego dzieła Adama Smitha Badania nad natura i przyczynami bogactwa narodów. Sama zbieżność w czasie skłania do porównań między

\footnotetext{
${ }^{43}$ Tenże, O podatkach..., s. 40-41.

${ }^{44}$ Tenże, O handlu..., s. 442.
} 
nimi, a tendencja ta jest tym silniejsza, że Hume’a i Smitha łączyła przyjaźń oraz zbliżone podejście do niektórych zagadnień. Jak wykazano, Hume miał też pod pewnymi względami wpływ na Smitha ${ }^{45}$. Część jego poglądów, szczególnie dotyczących roli pieniądza i handlu zagranicznego, czy wprowadzenie zmiennej czasowej w teorii pieniądza, pozwalały widzieć go jako osobę o bardzo zaawansowanych poglądach, wykraczających daleko poza jego epokę ${ }^{46}$. W rezultacie Hume jest przedstawiany jako prekursor liberalnej doktryny gospodarczej, czy nawet jako „prawdziwy ojciec ekonomii”, którego zasługi przez długi czas przemilczano, a to ze względu na fakt, że koncentrowano się na jego pracach filozoficznych ${ }^{47}$.

Pomijając osobiste zaangażowanie badaczy pozostających pod urokiem wielkich osiągnięć intelektualnych Hume’a, takie opinie są również efektem jednostronnego spojrzenia na merkantylizm. Przyczynił się do tego sam Hume, podkreślając w esejach odmienny od dominujących charakter swoich poglądów ${ }^{48}$. W podobny sposób postąpił Smith, przeciwstawiając swój system temu, co nazywał „systemem handlowym” bądź „systemem merkantylistycznym" ${ }^{49}$. Obydwaj odwołali się tylko do tych elementów występujących w merkantylizmie, które ułatwiały im przedstawienie ich własnych pomysłów. Jeśli jednak przyjąć, że merkantylizm nie był spójną doktryną ekonomiczną, lecz „zbiorem wzajemnie ze sobą powiązanych tekstów, które dotyczyły praktycznego wymiaru ówczesnej polityki ekonomicznej, przedstawiając równocześnie odmienne interpretacje sytuacji gospodarczej między mniej więcej 1620 a 1750 rokiem", a podobne były w nim tylko pytania, natomiast odpowiedzi różne, to należy wówczas przyjąć, że nie istniała spójna doktryna merkantylizmu ${ }^{50}$. W ciągu mniej więcej 130 lat w państwach o różnej strukturze politycznej, gospodarczej i społecznej, stojących przed

${ }^{45}$ E. Rotwein, Introduction, [w:] David Hume: Writings on Economics, ed. by E. Rotwein, T. Nelson and Sons, Edinburgh 1955, s. LXXVIII-LXXXI, CVI-CX; M. Arkin, The Economic Writings of David Hume - A Reassessment, [w:] Essays in Economic Thought. Aristotle to Marshall, ed. by J. J. Spengler and W. R. Allen, Chicago 1960, s. 142.

${ }^{46}$ R. Lyon, Notes on Hume's Philosophy of Political Economy, „Journal of the History of Ideas” 1970, vol. 31, no. 3 July/September, s. 457.

${ }^{47}$ M. Arkin, The Economic Writings..., s. 156.

${ }^{48}$ D. Hume, O handlu..., s. 441.

${ }^{49}$ A. Smith, Badania nad natura i przyczynami bogactwa narodów, przeł. A. Prejbisz, t. 2, ks. 4, Warszawa 2007, s. 8-35.

${ }^{50}$ L. Magnusson, Introduction, [w:] Mercantilism, ed. by L. Magnusson, t. 1, Routledge, London-New York 1995, s. 4. Wśród badaczy polskich, patrz: S. Zabieglik, Eseje ekonomiczne Davida Hume'a, „Nowa Krytyka” 2007, nr 20-21, s. 460-466; A. Markwart, Filozofia XVII wieku 
różnymi wyzwaniami musiały pojawić się odmienne poglądy na kwestie gospodarcze. Przeciwstawianie poglądów ekonomicznych Hume’a poglądom wyrażanym przez „merkantylistów” traci uzasadnienie, ponieważ nie było jednej grupy, którą można by określić tym mianem. Poglądy Hume’a różniły się od poglądów tych autorów, z którymi polemizował w esejach, ale znajdziemy też autorów, którzy formułowali poglądy zbliżone, czy nawet identyczne $\mathrm{z}$ jego opiniami. $Z$ dorobku „merkantylizmu” warto sięgnąć po opinie na temat ekonomii powstałe w rodzinnym kraju Hume’a, Szkocji, w okresie poprzedzającym początek jego działalności publicznej.

W kluczowej dla niego kwestii: czym jest bogactwo i jakie są jego źródła podobne stanowisko zajęło kilku pisarzy i polityków aktywnych w pierwszych latach XVIII wieku. Odrzucali pogląd, że bogactwo jest tożsame z pieniądzem, widząc go jako środek ułatwiający obrót gospodarczy: „Te metale [złoto i srebro] nie mają innej wartości, niż ta, którą zyskują dzięki użyciu w handlu" ${ }^{51}$. Nie był to oryginalny pogląd. Zbliżone stanowisko zajmował Charles Davenant, autor najważniejszych angielskich prac dotyczących ekonomii, a jeszcze wcześniej, bo na początku XVII wieku czynili to Edward Misselden i Thomas Munn $^{52}$. Zbieżne były również poglądy co do ilości pieniądza niezbędnego do funkcjonowania gospodarki. Szkoccy autorzy z początku XVIII wieku narzekali na brak pieniądza i zastanawiali się nad sposobami zwiększenia jego ilości, choćby poprzez emisję banknotów (pomysł odrzucany przez Hume’a). Postulowali jednak zwiększenie ilości pieniądza nie po to, aby zwiększyć bogactwo, którego przecież nie utożsamiali z pieniądzem, ale w tym celu, aby pobudzić rozwój ekonomiczny ${ }^{53}$. Takie stanowisko korespondowało z poglądem Hume’a, że stały, choć ograniczony napływ pieniądza przyczynia się do rozwoju gospodarczego. Zgadzali się też, że nadmierna ilość pieniądza, czyli taka, która nie znajduje zastosowania w gospodarce może stanowić za-

jako inspiracja dla prekursorów klasycznej myśli ekonomicznej, „Studia z Historii Filozofii” 2(4)/2013, s. 139-148.

${ }^{51}$ W. Seton, Some Thoughts, on Ways and Means For making This Nation a gainer in Foreign Commerce; And for Supplying Its present Scarcity of Money, Edinburgh 1705, s. 59.

${ }^{52}$ I. Hont, Free trade and economic limits to national politics: neo-Machiavellian political economy reconsidered, [w:] The economic limits to modern politics, ed. by J. Dunn, Cambridge 1990, s. 71; Mercantilism..., s. 49-230.

${ }^{53}$ W. Black, Essay upon Industry and Trade, Shewing The Necessity of the One, The Conveniency and Usefulness of the other, and the Advantages of Both, Edinburgh 1706, s. 4; W. Paterson, The Occasion of Scotland's Decay in Trade, with a proper expedient For Recovery thereof, And The Increase of our Wealth, b.m.w. 1705, s. 5; W. Seton, Some Thoughts..., s. 62. 
grożenie, ponieważ prowadzi do wzrostu $\operatorname{cen}^{54}$. Zgoda istniała również co do pochodzenia bogactwa. Jego źródłem była praca ludzi, jak stwierdził jeden z autorów: „Ponieważ to ludzie, poprzez swoją pracę i starania tworzą bogactwo i siłę każdego narodu" ${ }^{55}$. Stąd pogląd, który spotkamy też u Hume’a ${ }^{56}$, że im większa liczba mieszkańców, tym potencjalnie wyższy poziom zamożności, a co za tym idzie bogactwo i siła państwa ${ }^{57}$. Podobnie z opinią, że miarą siły państwa jest bogactwo, nie wielka armia, przy czym bogactwo i siła państwa są zależne od pomyślności jednostek. Na przełomie XVII i XVIII wieku w Anglii prowadzono spory, w których wziął udział między innymi Daniel Defoe, na temat siły miecza i siły sakiewki ${ }^{58}$. W Szkocji William Seton pisał: „to Królestwo [Szkocji] może być określone jako bogate, silne bądź szczęśliwe stosownie do zamożności i wygody życia swego ludu" 59 .

Różnice zdań pojawiły się natomiast w tak ważnej dla Hume’a kwestii handlu zagranicznego. Szkoccy autorzy zgodnie twierdzili, że handel zagraniczny jest jednym $z$ najważniejszych elementów gospodarki, posuwając się nawet do stwierdzeń, że ,jedynym sposobem na zwiększenie bogactwa naszego Królestwa jest to, co nazywamy handlem zagranicznym" ${ }^{60}$. Równocześnie podstawowym problemem Szkocji był brak pieniądza, na który powszechnie narzekano, widząc $\mathrm{w}$ nim przeszkodę na drodze do rozwoju ${ }^{61}$. Brak przypisywano deficytowi w handlu zagranicznym, zakładając, że najważniejszym

${ }^{54}$ W. Seton, Some Thoughts..., s. 64.

55 Tenże, The Interest of Scotland in three Essays, b.m.w. 1700, s. 54.

${ }^{56}$ D. Hume, Of the Populousness of Ancient Nations, [w:] Essays moral, political and literary, ed. by E. F. Miller, Indianapolis 1987, s. 381-382.

${ }^{57}$ G. Mackenzie, Parainesis Pacifica; or a perswasive to the Union of Britain. By a Person of Quality, London 1702, s. 7; J. Hodges, The Rights and Interests Of the Two British Monarchies. With a Special Respect to An United or Separate State. Treatise III. Containing Farther Inquiries into the Best Means for procuring a Happy Union betwixt the Two Kingdoms; with a Special Regard to the Argument, That the Making Both Nations ONE PEOPLE, must also Make them of ONE INTEREST, London 1706, s. 30.

${ }^{58}$ D. Defoe, An Argument Shewing, that a Standing Army, with Consent of Parliament, is not Inconsistent with a Free Government, [w:] Selected Writings of Daniel Defoe, ed. by J. T. Boulton, Cambridge 1975, s. 45-48.

${ }^{59}$ W. Seton, The Interest..., s. 73.

${ }^{60}$ T. W. Philopatris, An Essay Concerning Inland ad Foreign, Publick and Private Trade; together with some Overtures, shewing how a Company or National Trade, may be continued in Scotland, with the Advantages which will result therefrom, b.m. i d.w., s. 2.

${ }^{61}$ W. Lorimers to earl of Seafield, Cullen House, July 2d, 1701, [w:] Publications of the Scottish History Society, New Series, vol. III, Seafield Correspondence from 1685 to 1708, ed. by J. Grant, Edinburgh 1912, s. 331. 
zadaniem tej gałęzi handlu było uzyskanie nadwyżki i przyciągnięcie pieniądza. Stąd nawoływania do działań o charakterze reglamentacyjnym, takich jak ograniczenie bądź całkowita rezygnacja z handlu z państwami, z którymi odnotowywano ujemny bilans, także z Anglią̨ ${ }^{62}$ Takie poglądy wydają się potwierdzać negatywną ocenę sformułowaną przez Hume’a o „merkantylistach” owładniętych pogonią za pieniądzem, który mylili z bogactwem. Jest to jednak pobieżna ocena, która nie bierze pod uwagę ani sytuacji Szkocji, ani głównego powodu, dla którego zabiegano o napływ pieniądza. Ze względu na niepowodzenie prób założenia w ostatnich latach XVII wieku kolonii szkockiej na terenie Panamy, znanych jako Darien scheme i utracie w związku z tym około 1/4 całego kapitału płynnego, w Szkocji rzeczywiście brakowało pieniędzy. Próbowano je zdobyć nie w tym celu, aby zwiększyć bogactwo państwa, przecież obydwie sprawy rozdzielano, ale po to, aby pobudzić gospodarkę przez zwiększenie dostępnego kapitału oraz ułatwienie wymiany wewnętrznej, a ostatecznie wyrwać ją z długotrwałego kryzysu. Nie chodziło ani o gromadzenie pieniędzy, ani o tworzenie gospodarki autarkicznej, szkoccy autorzy zgodnie twierdzili, że wszelkie ograniczenia dotyczące handlu zagranicznego powinny mieć charakter tymczasowy, a kiedy tylko bilans ulegnie poprawie, powinny zostać zlikwidowane ${ }^{63}$. Stanęli przed problemami, które wymagały jak najszybszego rozwiązania i stąd częściowo brały się różnice między nimi a poglądami Hume’a. Na początku XVIII wieku Szkocja borykała się nie tylko z długotrwałym kryzysem ekonomicznym, ale stanęła również przed koniecznością określenia swojej przyszłości politycznej w postaci nowego związku z Anglią. Prace Hume’a dotyczące ekonomii powstały w całkowicie innej sytuacji. Wspomniany związek między Szkocją i Anglią funkcjonował od 1707 roku i po latach wreszcie zaczął przynosić korzyści gospodarce Szkocji. Hume mógł pozwolić sobie na rozważania teoretyczne, w których nie był ograniczony potrzebami chwili. Jego rady dotyczące zwiększenia ilości pieniądza $\mathrm{w}$ obiegu poprzez rezygnację $\mathrm{z}$,prostego, dawnego sposobu życia” wyglądały dobrze na papierze, ale ich realizacja wymagała-

${ }^{62}$ J. Clerk, The Circumstances of Scotland Consider'd, With Respect to the present Scarcity of Money: Together with some proposals For supplying the Defect thereof, And rectifying the Ballance of Trade, Edinburgh 1705, s. 24; W. Paterson, The Occasion..., s. 5; W. Black, Some Considerations in relation to Trade, Humbly Offered to His Grace Her Majesty's high Commissioner and the Estates of Parliament, b.m.w. 1706, s. 11.

${ }^{63}$ W. Paterson, The Occasion..., s. 5; W. Black, Some overtures and conditions in Relation to Trade and Cares, Humbly Offered to the Parliament. By a Well-wisher to his Country, b.m.w. 1706, s. 11. 
by bardzo długiego czasu. Mieszkańcy Szkocji żyjący w pierwszej dekadzie XVIII wieku tego czasu nie mieli. Warto jednak podkreślić, że pisarze szkoccy aktywni na początku XVIII wieku wyrażali podobne opinie kiedy odnosili się do zagadnień teoretycznych, takich jak rola pieniądza w gospodarce czy źródła bogactwa.

Powyższa ocena nie deprecjonuje osiągnięć Hume w dziedzinie ekonomii. Pozwala natomiast spojrzeć na jego dorobek w dłuższej perspektywie czasowej i dostrzec szereg podobieństw między nim a częścią autorów, którzy byli aktywni kilka dekad wcześniej. Hume, a po nim i Smith, nie wymyślił nowoczesnej ekonomii „od zera”. Niektóre z jego poglądów były oryginalne, ale większość nawiązywała w pozytywny sposób do dorobku „merkantylistów”, rozwijając go i dostosowując do zmieniających się warunków. Podobnie jak w przypadku, wydaje się oczywistego dla Hume’a pytania o to, czy ekonomia może być nauką, udzielenie jednoznacznej odpowiedzi na pytanie o miejsce Hume’a w historii myśli ekonomicznej z zastosowaniem ostrego podziału „merkantylista - liberał” jest niemożliwe. Taki sam problem mieli autorzy żyjący w czasach Hume’a. Jego dorobek był wykorzystany zarówno przez Adama Smitha, twórcę liberalnej doktryny ekonomicznej, jak i Jamesa Steuarta, który w pracy Principles of Political Oeconomy opowiadał się za polityką interwencjonizmu państwowego ${ }^{64}$. Warto więc zastanowić się nad zdaniem zamykającym jeden z esejów Hume’a poświęcony sytuacji politycznej Wielkiej Brytanii. Równie dobrze można odnieść tę uwagę do jego prac poświęconych ekonomii: „Być może, fakt ten [skomplikowana sytuacja polityczna] da nam lekcję umiarkowania we wszystkich naszych politycznych sporach"65.

\section{Bibliografia}

Arkin M., The Economic Writings of David Hume - A Reassessment, [w:] Essays in Economic Thought. Aristotle to Marshall, eds. J. J. Spengler, W. R. Allen, Rand McNally, Chicago 1960.

\footnotetext{
${ }^{64}$ A.S. Skinner, David Hume: Principles of political economy, [w:] The Cambridge Companion to Hume, ed. by D. F. Norton, Cambridge University Press, Cambridge 1993, s. 245-246.

${ }^{65} \mathrm{D}$. Hume, O tym, czy ustrój brytyjski skłania się raczej ku monarchii absolutnej, czy republice, przeł. M. Filipczuk, „Principia” XXXII-XXXIII (2002), s. 74.
} 
Black W., Essay upon Industry and Trade, Shewing The Necessity of the One, The Conveniency and Usefulness of the other, and the Advantages of Both, Edinburgh 1706.

Black W., Some Considerations in relation to Trade, Humbly Offered to His Grace Her Majesty's high Commissioner and the Estates of Parliament, b.m.w. 1706.

Black W., Some overtures and conditions in Relation to Trade and Cares, Humbly Offered to the Parliament. By a Well-wisher to his Country, b.m.w. 1706.

Clerk J., The Circumstances of Scotland Consider'd, With Respect to the present Scarcity of Money: Together with some proposals For supplying the Defect thereof, And rectifying the Ballance of Trade, Edinburgh 1705.

David Hume: Writings on Economics, ed. E. Rotwein, T. Nelson and Sons, Edinburgh 1955.

Defoe D., An Argument Shewing, that a Standing Army, with Consent of Parliament, is not Inconsistent with a Free Government, [w:] Selected Writings of Daniel Defoe, ed. J. T. Boulton, Cambridge Univeristy Press, Cambridge 1975.

Hodges J., The Rights and Interests Of the Two British Monarchies. With a Special Respect to An United or Separate State. Treatise III. Containing Farther Inquiries into the Best Means for procuring a Happy Union betwixt the Two Kingdoms; with a Special Regard to the Argument, That the Making Both Nations ONE PEOPLE, must also Make them of ONE INTEREST, London 1706.

Hont I., Free trade and economic limits to national politics: neo-Machiavellian political economy reconsidered, [w:] The economic limits to modern politics, ed. J. Dunn, Cambridge University Press, Cambridge 1990.

Hume D., Badania dotyczace rozumu ludzkiego wraz z apendyksami, przeł. D. Misztal i T. Sieczkowski, Wydawnictwo Zielona Sowa, Kraków 2004.

Hume D., Eseje z dziedziny moralności, polityki i literatury, przeł. Ł. Pawłowski, Wydawnictwo Uniwersytetu Warszawskiego, Warszawa 2013.

Hume D., O handlu, przeł. S. Zabieglik, „Nowa Krytyka” t. 20-21 (2007).

Hume D., O kredycie publicznym, przeł. A. Grzeliński i A. Markwart, „Studia z Historii Filozofii" 1(7)/2016.

Hume D., O pieniądzu, przeł. A. Grzeliński, „Studia z Historii Filozofii” 1(5)/2014.

Hume D., O podatkach, przeł. S. Zabieglik, „Pieniądze i Więź”, rok II, nr 2 (7) wiosna 2000.

Hume D., O procencie, przeł. A. Grzeliński i K. Wawrzonkowski, „Studia z Historii Filozofii" 4(5)/2014.

Hume D., O równowadze handlu, przeł. D. Kosiewicz-Wawrzonkowska, „Studia z Historii Filozofii" 1(6)/2015.

Hume D., O studiowaniu historii, przeł. P. Michalski, „Nowa Krytyka”, t. 20-21 (2007).

Hume D., O tym, czy ustrój brytyjski skłania się raczej ku monarchii absolutnej, czy republice, przeł. M. Filipczuk, „Principia” t. XXXII-XXXIII (2002).

Hume D., O zawiści w handlu, przeł. K. Wawrzonkowski, „Studia z Historii Filozofii” $4(6) / 2015$. 
Hume D., Of the Populousness of Ancient Nations, [w:] Essays moral, political and literary, ed. E. F. Miller, Liberty Fund, Indianapolis 1987.

Hume D., Traktat o naturze ludzkiej, przeł. C. Znamierowski, Fundacja Aletheia, Warszawa 2005.

Kopczyńska K., Zabieglik S., Psychologia ekonomiczna Davida Hume’a, „Nowa Krytyka" 20-21 (2007).

Lyon R., Notes on Hume's Philosophy of Political Economy, "Journal of the History of Ideas", vol. 31, no. 3 July/September 1970.

Mackenzie G., Parainesis Pacifica; or a perswasive to the Union of Britain. By a Person of Quality, London 1702.

Markwart A., Filozofia XVII wieku jako inspiracja dla prekursorów klasycznej myśli ekonomicznej, „Studia z Historii Filozofii” 2(4)/2013.

Mercantilism, ed. L. Magnusson, t. 1, Routledge, London-New York 1995.

Paterson W., The Occasion of Scotland's Decay in Trade, with a proper expedient For Recovery thereof, And The Increase of our Wealth, b.m.w. 1705.

Philopatris T. W., An Essay Concerning Inland ad Foreign, Publick and Private Trade; together with some Overtures, shewing how a Company or National Trade, may be continued in Scotland, with the Advantages which will result therefrom, b.m. i d. w.

Publications of the Scottish History Society, New Series, vol. III, Seafield Correspondence from 1685 to 1708, ed. J. Grant, Scottish History Society, Edinburgh 1912.

Seton W., Some Thoughts, on Ways and Means For making This Nation a gainer in Foreign Commerce; And for Supplying Its present Scarcity of Money, Edinburgh 1705.

Seton W., The Interest of Scotland in three Essays, b.m.w. 1700.

Skinner A. S., David Hume: Principles of political economy, [w:] The Cambridge Companion to Hume, ed. D. F. Norton, Cambridge University Press, Cambridge 1993.

Smith A., Badania nad natura i przyczynami bogactwa narodów, t. 2, Państwowe Wydawnictwo Naukowe, Warszawa 2007.

Zabieglik S., Eseje ekonomiczne Davida Hume’a, „Nowa Krytyka” 20-21 (2007).

\section{Abstract \\ David Hume: That Economics may be Reduced to a Science}

The title of this article refers to one of the best-known essays written by David Hume, That Politics may be reduced to a Science. Hume assumed that politics was a science because it admitted of some general truths, which could not be varied by human beings. He adopted a similar stance, albeit indirectly, in the case of economics, 
discovering several general truths concerning the origins of wealth, money and international trade. At times, however, he was far from being consistent and this undermined these truths. Consequently, it can be argued that, from his perspective, economics was a science on a theoretical level, but it lost this character at a more practical level. Similar doubts can be raised when it comes to Hume's role in the history of economic thought. In some respects he was an original thinker, but several of his key concepts resembled to some extent ideas that had been put forward by 'mercantilists', especially those 'mercantilists' who were active in his native Scotland in the first decade of the $18^{\text {th }}$ century.

Key words: David Hume, science, economics, Scotland 